\title{
Mediasi Komitmen Organisasi Dalam Meningkatkan Kinerja Karyawan PT Perkebunan Nusantara VIII Provinsi Jawa Barat
}

\author{
Dr. Budi Rismayadi, SE.,MM \\ Program Studi Manajemen, Fakultas Bisnis dan Ilmu Sosial Universitas Buana Perjuangan, \\ Karawang, Indonesia \\ budi.rismayadi@ubpkarawang.ac.id
}

\begin{abstract}
Abstrak
Penelitian ini bertujuan untuk membuktikan dan menganalisis peningkatan kinerja karyawan melalui peningkatan kepuasan kerja yang dimediasi oleh komitmen organisasi. Populasi dalam penelitian ini adalah karyawan PT Perkebunan Nusantara VIII Provinsi Jawa Barat. Metode penelitian yang digunakan dalam penelitian ini adalah metode survey deskriptif dan survey eksplanatori dengan ukuran sampel minimum 200 responden, dengan metode analisis data yang digunakan adalah SEM (Structural Equation Modeling). Berdasarkan hasil penelitian, didapatkan temuan sebagai berikut kepuasan kerja berpengaruh positif dan signifikan secara langsung terhadap komitmen organisasi dan kinerja karyawan, komitmen organisasi berpengaruh positif dan signifikan terhadap kinerja karyawan, kepuasan kerja berpengaruh terhadap kinerja karyawan melalui komitmen organisasi, kepuasan kerja dan komitmen organisasi secara simultan berpengaruh positif dan signifikan terhadap kinerja karyawan dengan kontribusi $\left(R^{2}\right)$ sebesar $88 \%$. Kepuasan kerja secara parsial berpengaruh paling dominan terhadap kinerja karyawan. Temuan penelitian menunjukkan juga bahwa komitmen organisasi merupakan partial mediating pada pengaruh kepuasan kerja terhadap kinerja karyawan.
\end{abstract}

Kata Kunci: Kepuasan Kerja, Komitmen Organisasi, Kinerja Karyawan

\section{Pendahuluan}

Kementerian Pertanian pada 2012-2016 menyatakan bahwa teh merupakan produk subsektor perkebunan yang menjadi salah satu komoditas unggulan nasional. Hal ini ditunjukkan dengan komoditas teh yang merupakan salah satu dari beberapa komoditas ekspor yang turut memberikan kontribusi cukup besar dalam menghasilkan devisa negara. Pada tahun 2016, komoditas ini berhasil menyumbang sebesar 124,8 juta US\$ (BPS, 2017).

Indonesia saat ini tergolong sebagai negara produsen terbesar kedelapan dengan jumlah produksi sebesar 142.400 metric ton dengan urutan pertama negara produsen terbesar adalah China (FAOSTAT, 2016). Jika dilihat berdasarkan negara pengekspor terbesar, Indonesia sebagai negara pengekspor teh menduduki posisi kelima dengan kontribusi sebesar $6 \%$ di bawah Sri Lanka yang mencapai 20\%, Kenya 19\%, selanjutnya di bawah China dan India yang masingmasing dengan kontribusi mencapai 18\% dan 14\% (Dewan Teh Kenya, 2011). Sementara tahun 2012, Indonesia mengalami penurunan peringkat menjadi urutan ke enam dengan kontribusi 
hanya sebesar 5,03\% (Dewan Teh India, 2012).

Sampai dengan tahun 2013 luas lahan perkebunan teh Indonesia mengalami penurunan yang mencapai 30 ribu hektar dalam kurun waktu sepuluh tahun atau hanya tersisa seluas 120 ribu hektar (Dewan Teh Indonesia, 2013). Produksi teh Indonesia mencapai sekitar 150 ribu ton per tahun dengan 80 ribu ton adalah untuk ekspor. Namun demikian impor teh masih mencapai 20 ribu ton per tahun serta cenderung mengalami peningkatan (Dewan Teh Indonesia, 2013)

Peningkatan impor teh dari negara-negara pengimpor teh yang cenderung terus meningkat berdampak pada perusahaan-perusahaan teh, khususnya perusahaan-perusahaan negara dalam hal ini adalah PT Perkebunan Nusantara (Persero) I sampai dengan XIV. Sementara dalam jumlah sumber daya manusia Perkebunan teh menyerap pekerja yang lebih besar bila dibandingkan dengan pekerja pada perkebunan lainnya. Disisi lain di Indonesia tingkat konsumsi teh hanya mencapai 180 gram perkapita per tahun, mengalami penurunan yang mencapai $45,45 \%$ yang sebelumnya mencapai 330 gram perkapita per tahun.

PT Perkebunan Nusantara VIII (Persero) adalah perusahaan milik Negara (BUMN) yang salah satu usahanya pada bidang Perkebunan teh yang berkedudukan di Provinsi Jawa Barat, dengan hasil produk teh yang mampu memenuhi pasar dalam negeri maupun kebutuhan pasar luar negeri (ekspor). Dalam situasi lingkungan dan persaingan bisnis Perkebunan yang semakin ketat serta dengan tantangan terus meningkat, dimana PT Perkebunan Nusantara VIII (Persero) mengelola teh dengan kebun sendiri maupun menampung hasil produksi rakyat, selama tahun 2016 jelas menghadapi kondisi lingkungan bisnis yang berat. Dengan komposisi porto folio bisnis perusahaan teh, perusahaan ikut berkontribusi terhadap luas areal maupun produksi komoditas tersebut di Indonesia. Namun berdasarkan pada kinerja perusahaan yang diukur dengan tingkat profitabilitas PT Perkebunan Nusantara VIII (Persero) sampai dengan tahun 2016 menunjukkan kecenderungan yang menurun. Sampai dengan tahun 2013 perusahaan masih mampu meningkatkan profit mencapai $12,53 \%$ dari sebelumnya yang hanya $10,20 \%$. Namun pada tahun 2015 dan bahkan tahun 2016 mengalami penurunan profit yang sangat besar, dimana profit tahun 2014 sebesar Rp. 181.555 Milyar turun menjadi Rp. 146.786 Milyar atau mengalami penurunan yang mencapai 19,15\%. Kemudian profit yang diperoleh pada tahun 2016 jauh lebih menurun hanya mampu mencapai Rp. 66.687 Milyar atau terjadi penurunan yang sangat drastis yang mencapai 54,57\% dibanding dengan tahun sebelumnya (Annual Report PTPN VIII (Persero), 2016). Kemudian berdasarkan Laporan Keuangan perusahaan tahun 2016 dengan pembanding tahun 2015 kondisi kesehatan perusahaan sebagai BUMN Perkebunan diukur dengan SK Menteri BUMN N0. 100/2002. Perusahaan tahun 2016 dalam Kondisi Sehat AA dengan skor 89,66 mengalami penurunan dari tahun sebelumnya, dimana tahun 2015 dalam 
Kondisi Sehat AAA dengan skor 95,5.

Banyak faktor yang dapat menyebabkan kinerja PT Perkebunan Nusantara VIII (Persero), seperti kebijakan ekonomi pemerintah, kebijakan pasar dunia, teknologi, permodalan, dan bahkan sumber daya manusia yang lebih memiliki peranan yang sangat penting dalam menjalan roda bisnis perusahaan. Menurut Kiran Fatima and Samreen Lodhi (2015:169) dalam penelitiannya yang menyatakan bahwa terdapat dampak positif yang kuat dari kinerja karyawan pada pencapaian tujuan organisasi. Demikian juga Mahmood, Iqbal and Samsaa (2014:86) dalam penelitiannya menyatakan bahwa kinerja karyawan adalah faktor yang paling penting dalam keberhasilan organisasi karena itu, ada kebutuhan untuk mengadopsi strategi sumber daya manusia yang efektif yang bertujuan untuk meningkatkan kinerja karyawan dan menciptakan budaya kinerja tinggi di setiap organisasi berdasarkan praktik sumber daya manusia.

Berdasarkan pernyataan tersebut di atas, maka rendahnya kinerja perusahaan PT Perkebunan Nusantara VIII (Persero) disebabkan oleh masih relatif rendahnya kinerja karyawan. Rendahnya kinerja karyawan PT Perkebunan Nusantara VIII (Persero) terlihat dari komposisi porto folio bisnis perusahaan teh pada laporan tahunan (2016) yang menunjukkan tingkat produksi teh mengalami penurunan dengan rata-rata setiap tahun mencapai $2,867 \%$ per tahun. Rendahnya kinerja karyawan PT Perkebunan Nusantara VIII (Persero), khususnya pada unit usaha teh terlihat juga dari data hasil survey awal peneliti (2017) pada karyawan, dimana sebagian besar karyawan PT Perkebunan Nusantara VIII belum menunjukkan tingkat hasil kerja yang masih di bawah target yang ditetapkan unit usaha perusahaan $(83,70 \%)$, demikian juga dengan beberapa kinerja karyawan lainnya seperti tingkat kualitas kerja umumnya masih di bawah standar minimum $(95,40 \%)$, masih kurangnya dalam bekerjasama baik dengan rekan kerja maupun dengan pimpinan/atasan $(90,30 \%)$, serta masih rendahnya karyawan dalam membantu karyawan lain atau rekan kerja $(91,20 \%)$.

Banyak faktor yang menyebabkan rendahnya kinerja karyawan, Muhammad Riaz Khan et. al. (2010:292) menyatakan berdasarkan hasil penelitiannya bahwa adanya hubungan positif antara komitmen organisasi dan kinerja karyawan. Masih menurut Muhammad Riaz Khan et. al., bahwa hasil analisis komparatif dari tiga dimensi komitmen organisasi, komitmen normatif memiliki dampak positif dan signifikan terhadap kinerja karyawan. Demikian juga dengan hasil penelitian Memari, Mahdieh and Barati (2013:164) yang menyatatakan bahwa hasil menunjukkan hubungan positif antara komitmen organisasi dan kinerja pekerjaan karyawan. Berdasarkan pernyataan hasil penelitian tersebut, maka rendahnya kinerja karyawan unit usaha PT Perkebunan Nusantara VIII (Persero) cenderung disebabkan oleh masih relatif rendahnya komitmen organisasi. Rendahnya komitmen organisasi pada unit usaha teh PT Perkebunan 
Nusantara VIII (Persero) diindikasikan berdasarkan pada data Human Resources and Development PT Perkebunan Nusantara VIII (2016), yang menunjukkan masih belum tercapainya "Komit Sistem" yang berlaku di perusahaan PTPN VIII yang mencakup kompetensi yang merupakan komitmen perusahaan untuk memiliki kemampuan untuk menerapkan dan mengembangkan pengetahuan, keterampilan dan keahlian (hard \& soft) yang dimiliki demi kepentingan dan kemajuan perusahaan; integritas untuk melaksanakan pekerjaan dengan jujur, bertanggung jawab, dan beretika, serta menyelaraskan setiap aksi korporat dengan kepentingan dan tata nilai perusahaan (corporate values) ; spirit untuk memiliki antusiasme dan semangat yang tinggi dalam bekerja; sadar biaya untuk menjalankan setiap rencana dan aksi korporat berdasarkan pertimbangan efisiensi dan efektivitas; dan team work untuk melaksanakan setiap aktivitas organisasi dengan semangat tim, sinergi dan kekompakan untuk mencapai visi dan prestasi bersama.

Menurut data dari HRD PTPN VIII (2016), Komit Sistem untuk kompetensi sebesar 80\%, untuk Integritas sebesar 85\%, untuk Spirit sebesar 70\%, untuk Sadar Biaya sebesar 60\%, dan untuk Team Work sebesar 70\%. Hasil ini menunjukkan bahwa komitmen organisasi pada PT Perkebunan Nusantara VIII belum mencapai $100 \%$ sesuai dengan standar pencapaian pencapaian "Komit Sistem", secara keseluruhan komit sistem hanya baru mencapai sekitar 73\%, dengan pencapaian komitmen tertinggi adalah pada aspek integritas yang mencapai 85\% sementara yang paling rendah adalah pada aspek komitmen sadar biaya sebesar $60 \%$.

Faktor lain yang dapat menyebabkan rendahnya kinerja karyawan, menurut Aftab Hira and Idrees Waqas (2012:174) menyimpulkan hasil penelitiannya bahwa ada hubungan positif antara kepuasan kerja dan prestasi kerja. Demikian juga dengan hasil penelitian yang dilakukan oleh Abdulrahman Ahmed Bako (2012:48), dengan hasil temuan penelitiannya adalah ada pengaruh yang signifikan dari kepuasan kerja terhadap kinerja karyawan dalam organisasi, kepuasan karyawan yang tinggi menyebabkan berkurangnya jumlah karyawan, karyawan yang puas tinggi memiliki kecenderungan produksi tinggi daripada pekerja yang puas rendah, dan kinerja karyawan secara keseluruhan tergantung pada sifat mereka kepuasan terhadap pekerjaan.

Berdasarkan pernyataan dari kedua hasil penelitian di atas, maka rendahnya komitmen organisasi dan kinerja karyawan pada unit usaha teh PT Perkebunan Nusantara VIII (Persero) diduga disebabkan oleh masih relatif rendahnya kepuasan kerja. Hal ini diindikasikan berdasarkan pada hasil observasi langsung peneliti (2017) terhadap karyawan PT Perkebunan Nusantara VIII (Persero). Hasil observasi tersebut menunjukkan angka ketidakpuasan karyawan atas kurangnya penghargaan yang menapai $19.25 \%$, ketidakpuasan atas adanya konflik horisontal mencapai $18.75 \%$, akibat konflik vertikal sebesar $12.5 \%$, ketidakpuasan atas 
kesempatan promosi mencapai $17 \%$, dan ketidakpuasan atas kenyamanan kerja sebesar $14.5 \%$. Adapun ketidakpuasan karyawan pada PT Perkebunan Nusantara VIII (Persero) secara keseluruhan mencapai rata-rata 16,40\% dengan tingkat ketidakpuasan karyawan yang tertinggi adalah pada ketidakpuasan atas penghargaan yang mencapai 19,25\%.

\section{Rumusan Masalah}

Berdasarkan latar belakang penelitian dan identitifikasi masalah di atas, maka rumusan masalah penelitian ini adalah sebagai berikut:

1. Apakah terdapat pengaruh kepuasan kerja terhadap komitmen organisasi dan kinerja karyawan pada karyawan PT Perkebunan Nusantara VIII (Persero) Provinsi Jawa Barat?

2. Apakah terdapat pengaruh komitmen organisasi terhadap kinerja karyawan PT Perkebunan Nusantara VIII (Persero) Provinsi Jawa Barat?

3. Apakah terdapat pengaruh komitmen organisasi terhadap kinerja karyawan melalui komitmen organisasi padaPT Perkebunan Nusantara VIII (Persero) Provinsi Jawa Barat?

4. Apakah terdapat pengaruh kepuasan kerja dan komitmen organisasi secara simultan terhadap kinerja karyawan PT Perkebunan Nusantara VIII (Persero) Provinsi Jawa Barat?

\section{Tujuan Penelitian}

Berdasarkan identifikasi dan rumusan masalah di atas, maka tujuan penelitian ini untuk mengetahui dan menganalisis:

1. Pengaruh kepuasan kerja terhadap komitmen organisasi dan kinerja karyawan pada karyawan PT Perkebunan Nusantara VIII (Persero) Provinsi Jawa Barat.

2. Pengaruh komitmen organisasi terhadap kinerja karyawan PT Perkebunan Nusantara VIII (Persero) Provinsi Jawa Barat.

3. Pengaruh komitmen organisasi terhadap kinerja karyawan melalui komitmen organisasi padaPT Perkebunan Nusantara VIII (Persero) Provinsi Jawa Barat.

4. Pengaruh kepuasan kerja dan komitmen organisasi secara simultan terhadap kinerja karyawan PT Perkebunan Nusantara VIII (Persero) Provinsi Jawa Barat.

\section{Tinjauan Teori}

\section{Kepuasan Kerja}

Robbins dan Judge (2013: 109) mendefinisikan kepuasan kerja sebagai perasaan positif tentang pekerjaan seseorang yang dihasilkan dari evaluasi karakteristiknya. Sementara Brooke et al. dalam Bellou (2010: 5) menyatakan bahwa kepuasan kerja mencerminkan sikap umum seorang individu terhadap pekerjaan, berasal dari pemuasan kebutuhan dan keinginan, sedangkan Hirschfeld dalam Bellou (2010: 5) menyebutkan kepuasan kerja merupakan ekspresi perasaan seseorang tentang pekerjaannya. 
Sedangkan Gibson et al. (2012: 102) mengemukakan bahwa kepuasan kerja adalah sikap yang dimiliki individu terhadap pekerjaan mereka. Hasil ini merupakan persepsi mereka tentang pekerjaan mereka, berdasarkan faktor-faktor lingkungan kerja, seperti gaya penyelia, kebijakan, dan prosedur, afiliasi kelompok kerja, kondisi kerja, dan tunjangan. Schleicher, Watt dan Greguras dalam Gibson et al. (2012: 102) mengutarakan dimensi yang dikaitkan dengan kepuasan kerja, terdapat lima secara khusus memiliki karakteristik penting yaitu; (1) Penghasilan/gaji yaitu jumlah yang diterima dan ekuitas yang dirasakan, (2) pekerjaan sendiri yaitu sejauh mana tugas-tugas pekerjaan dianggap menarik dan memberikan kesempatan untuk belajar dan untuk menerima tanggung jawab, (3) peluang promosi yaitu ketersediaan kesempatan untuk kemajuan, (4) supervisor yaitu kemampuan pengawas untuk menunjukkan minat dan kepedulian terhadap karyawan dan (5) rekan kerja yaitu sejauh mana rekan kerja ramah, kompeten, dan mendukung.

\section{Komitmen Organisasi}

Menurut Lennick, Dough dan Fred (2008: 176) bahwa memiliki orang yang tepat yaitu orang-orang yang memiliki dan menjalankan nilai-nilai organisasi merupakan pengungkit utama dalam membangun sebuah organisasi yang kompeten secara moral. Menurut Robbins dan Judge (2013: 108) menyatakan bahwa komitmen organisasi adalah tingkat seorang karyawan mengidentifikasi dengan organisasi tertentu dan tujuan serta keinginan untuk mempertahankan keanggotaan dalam organisasi. Sedangkan Hellriegel dan Slocum (2011: 91) menambahkan bahwa karyawan yang sangat berkomitmen akan melihat diri mereka sebagai anggota yang berdedikasi terhadap organisasi.

Allen dan Meyer dalam George dan Jones (2012: 88) mengidentifikasi dua jenis yang berbeda dari komitmen individu yaitu komitmen afektif dan komitmen kontinu. Karena alam multidimensi komitmen organisasi ini, ada dukungan yang berkembang untuk model tiga komponen yang diusulkan oleh Meyer dan Allen dalam Luthans (2011: 148), dua dimensi telah dibahas sebelumnya, satu dimensi lagi adalah komitmen normatif yaitu melibatkan perasaan karyawan akan kewajiban untuk tinggal dengan organisasi karena mereka harus, hal itu adalah benar untuk dilakukan.

\section{Kinerja Karyawan}

Gomes (2005: 39) menyatakan kinerja pegawai sebagai catatan hasil produksi pada fungsi pekerjaan yang spesifik atau aktivitas selama periode waktu tertentu. Sehingga kinerja merupakan tingkat keberhasilan yang diraih oleh pegawai dalam melakukan suatu aktivitas kerja dengan merujuk pada tugas yang harus dilakukan. Menurut Gomes (2005:45) mengemukakan 
beberapa tipe kinerja karyawan yaitu quantity of work, quality of work, job knowledge, creativeness, cooperative, dependability, initiative, dan personal qualities.

Mangkunegara (2007: 9) menyatakan bahwa kinerja karyawan adalah hasil kerja secara kualitas dan kuantitas yang dicapai oleh seseorang karyawan dalam melaksanakan tugasnya sesuai dengan tanggung jawab yang diberikan kepada karyawan tersebut. Kinerja individual merupakan hubungan dari ketiga faktor antara lain kemampuan (ability), usaha (effort), dan dukungan (support). Mangkunegara (2007: 75) menyatakan mengenai empat faktor kinerja pegawai sebagai standar penilaian kinerja, yaitu kualitas kerja, kuantitas kerja, keandalan, dan sikap.

\section{Kerangka Pemikiran}

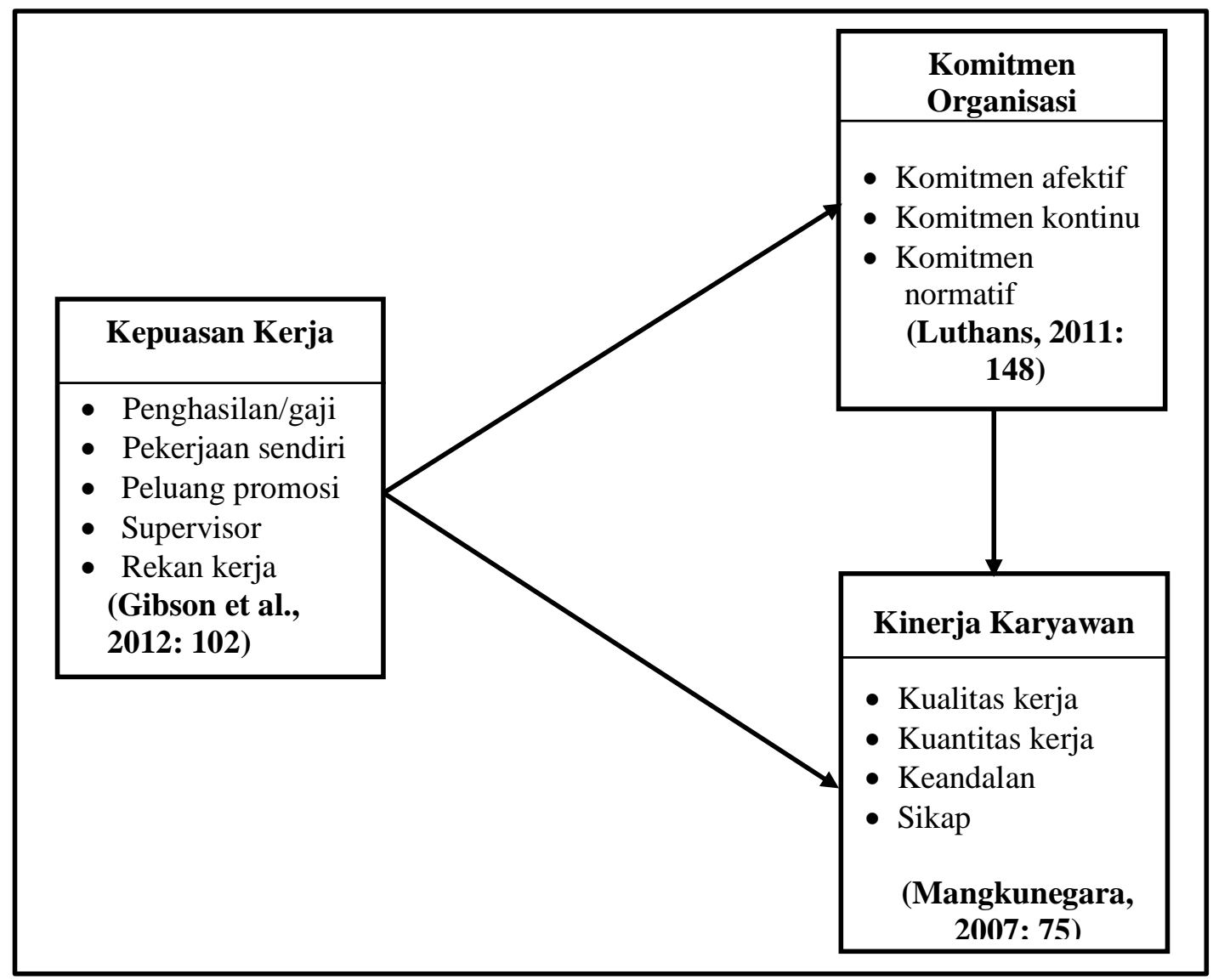

Gambar 1. Kerangka Pemikiran

\section{Hipotesis Penelitian}

Berdasarkan uraian kerangka pemikiran dan mengacu pada model penelitian di atas maka hipotesis penelitian adalah sebagai berikut:

H1 : Terdapat pengaruh kepuasan kerja terhadap komitmen organisasi dan kinerja karyawan karyawan pada PT Perkebunan Nusantara VIII (Persero) Provinsi Jawa Barat. 
H2 : Terdapat pengaruh kepuasan kerja terhadap komitmen organisasi pada PT Perkebunan Nusantara VIII (Persero) Provinsi Jawa Barat.

H3 : Terdapat pengaruh kepuasan kerja terhadap kinerja karyawan melalui komitmen organisasi pada PT Perkebunan Nusantara VIII (Persero) Provinsi Jawa Barat.

H4 : Terdapat pengaruh kepuasan kerja dan komitmen organisasi secara simultan terhadap kinerja karyawan PT Perkebunan Nusantara VIII (Persero) Provinsi Jawa Barat

\section{Metode Yang Digunakan}

Objek penelitian yang menjadi variabel bebas dalam penelitian ini adalah kepuasan kerja. Sedangkan yang menjadi variabel terikat adalah komitmen organisasi dan kinerja karyawan. Sifat penelitian ini adalah bersifat deskriptif dan verifikatif. Mengingat sifat penelitian ini adalah deskriptif dan verifikatif yang dilaksanakan melalui pengumpulan data di lapangan, maka metode penelitian yang digunakan adalah metode descriptive survey dan metode explanatory survey. Unit analisis dalam penelitian ini adalah para karyawan di lingkungan PT Perkebunan Nusantara VIII (Persero) Provinsi Jawa Barat. Time horizon dalam penelitian ini adalah crossectional, dimana penelitian dilakukan dalam satu waktu secara serentak.

Populasi merupakan objek yang berada pada suatu wilayah dan memenuhi syarat-syarat tertentu berkaitan dengan masalah penelitian. Jenis populasi yang digunakan dalam penelitian ini adalah populasi terbatas yaitu populasi yang mempunyai sumber data yang jelas batasnya secara kuantitatif sehingga dapat dihitung jumlahnya. Dalam penelitian ini yang dijadikan unit analisis (populasi) adalah Unit Usaha Teh PT Perkebunan Nusantara VIII (Persero) Provinsi Jawa Barat.

Berkaitan ketetapan pada SEM, Hatcher (1994) menyatakan bahwa dalam menentukan ukuran sampel, terdapat rasio minimum yaitu 5 responden untuk setiap parameter dalam penelitian, atau 10 responden untuk setiap 1 parameter, atau 15 responden untuk setiap 1 parameter. Demikian juga Hair et, al (2010:605) menyatakan tidak ada kriteria tunggal untuk menentukan ukuran sampel dalam SEM, namun perlu diperhatikan rasio sampel terhadap parameter agar mencapai rasio $1: 5$. Berdasarkan ketetapan dalam SEM tersebut, maka dalam penelitian ini digunakan perbandingan $1: 5$ atau 1 kuesioner (indikator) dengan 5 responden. Penelitian ini memiliki 40 parameter (indikator), maka ukuran sampel minimal adalah:

$\mathrm{n}=$ jumlah parameter $\times 5=40 \times 5=200$ responden

Dengan demikian, ukuran minimal sampel yang diambil dalam penelitian ini adalah sebesar 200 responden. Sedangkan pemilihan sampel dari populasi digunakan teknik proportionate stratified random sampling. Menurut Sugiyono (2013 : 64) yang dimaksud dengan proportionate stratified random sampling adalah teknik pengambilan sampel bila populasi mempunyai anggota/unsur yang tidak homogen dan berstrata secara proporsional.

\section{Pembahasan}


Tabel 1. Ukuran Kesesuaian Model Keseluruhan (Hybrid Model) SEM

\begin{tabular}{cccc}
\hline $\begin{array}{c}\text { Indikator } \\
\text { GOF }\end{array}$ & $\begin{array}{c}\text { Ukuran yang } \\
\text { Diharapkan }\end{array}$ & Hasil Estimasi & Kesimpulan \\
\hline Ukuran & Absolute Fit & \\
\hline GFI & GFI $>0,90$ & 0,95 & Good Fit \\
\hline RMSEA & RMSEA $<0,08$ & 0,062 & Good Fit \\
\hline & Ukuran Incremental Fit & \\
\hline NNFI & NNFI $>0,90$ & 0,90 & Good Fit \\
\hline NFI & NFI $>0,90$ & 0,90 & Good Fit \\
\hline AGFI & AGFI $>0,90$ & 0,84 & Marginal Fit \\
\hline RFI & RFI $>0,90$ & 0,88 & Marginal Fit \\
\hline IFI & IFI $>0,90$ & 0,91 & Good Fit \\
\hline CFI & CFI $>0,90$ & 0,91 & Good Fit
\end{tabular}

Sumber : Hasil Pengolahan dengan LISREL 8.80

Berdasarkan Tabel 1 di atas, enam ukuran kesesuaian yang diperoleh memiliki indeks kesesuaian model pengukuran yang good fit yaitu GFI, RMSEA, NNFI, NFI, IFI dan CFI. Sementara dua ukuran kesesuaian lainnya memiliki indeks kesesuaian model pengukuran yang marginal fit yaitu AGFI dan RFI. Dengan demikian maka dapat dilanjutkan pada analisis pengukuran berikutnya.

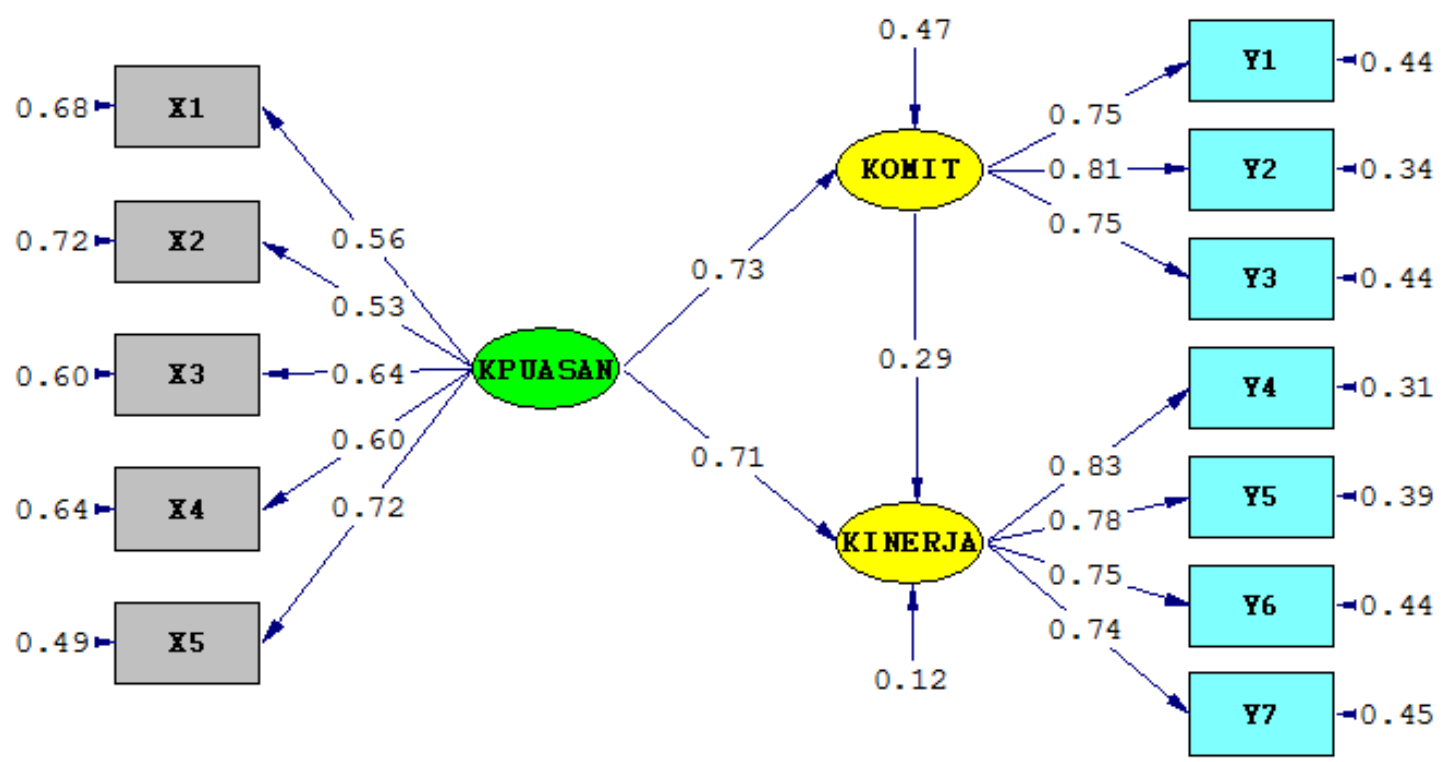

Chi-Square $=362.91, \mathrm{df}=51, \mathrm{P}-\mathrm{value}=0.00000, \mathrm{RMSEA}=0.062$

Gambar 2. Model SEM Standardized 


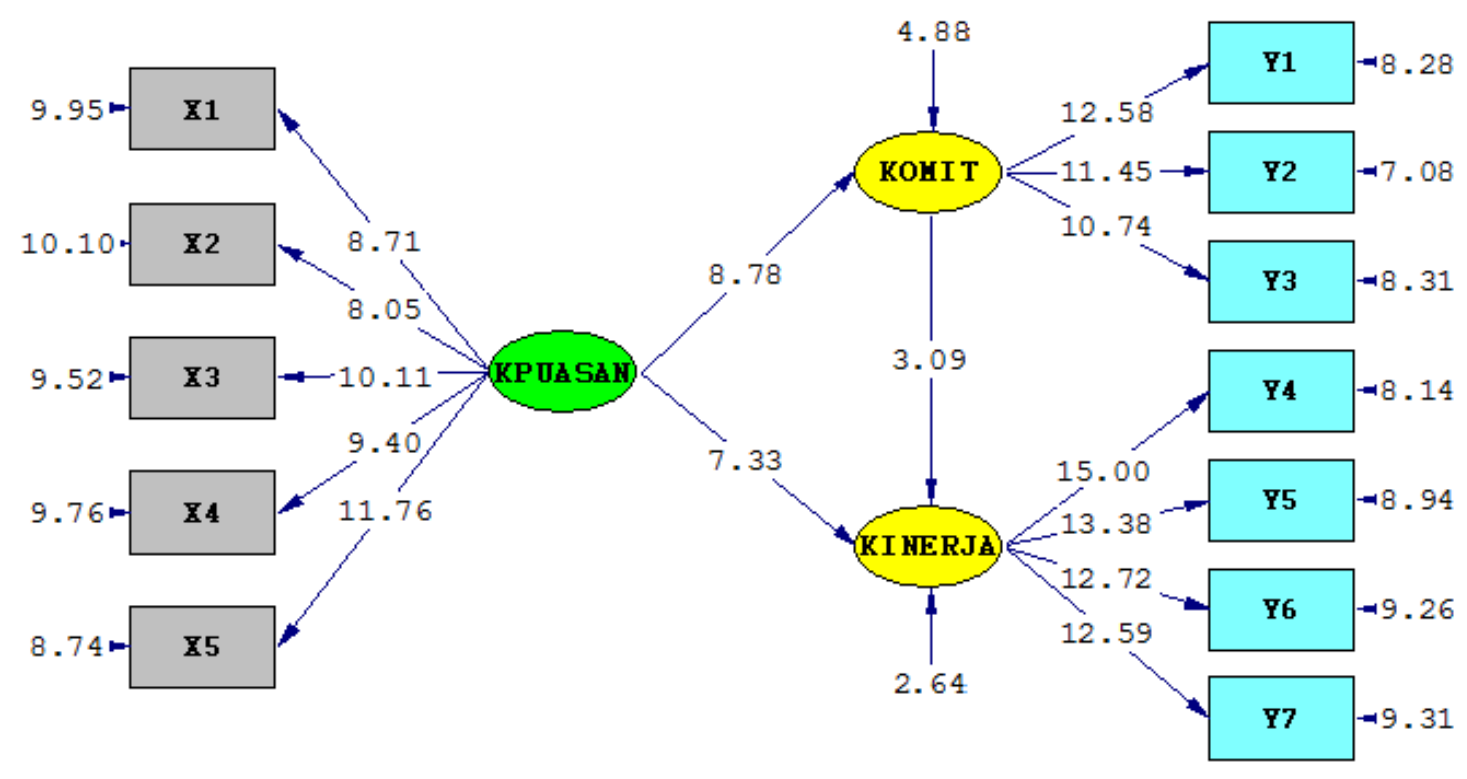

Chi-Square $=362.91, \mathrm{df}=51, \mathrm{P}-\mathrm{value}=0.00000, \mathrm{RMSEA}=0.062$

\section{Gambar 3. Model SEM t-value}

Berdasarkan Gambar 2 dan Gambar 3 di atas, selanjutnya adalah melakukan analisis model pengukuran model SEM dari setiap variabel, dimana untuk semua indikator dalam pembentukan variabel laten eksogen Kepuasan Kerja maupun variabel laten endogen Komitmen Organisasi dan Kinerja Karyawan memiliki validitas yang baik, hal ini ditunjukkan dengan semua indikator memiliki Standardized Loading Factor (SLF) $\geq 0,5$ dan nilai $t_{\text {hitung }} \geq 1,96$ (pada $\alpha=0,05$ ) (Hair, at.all., 2010). Demikian juga baik variabel laten eksogen maupun endogen memiliki reliabilitas model yang baik, hal ditunjukkan dengan semua variabel memiliki nilai construct reliability yang lebih besar dari $0,70(\mathrm{CR}>0,70)$ dan nilai variance extract lebih besar dari $0,50(\mathrm{VE}>0,50)$.

Tabel 2. Model Persamaan Struktural

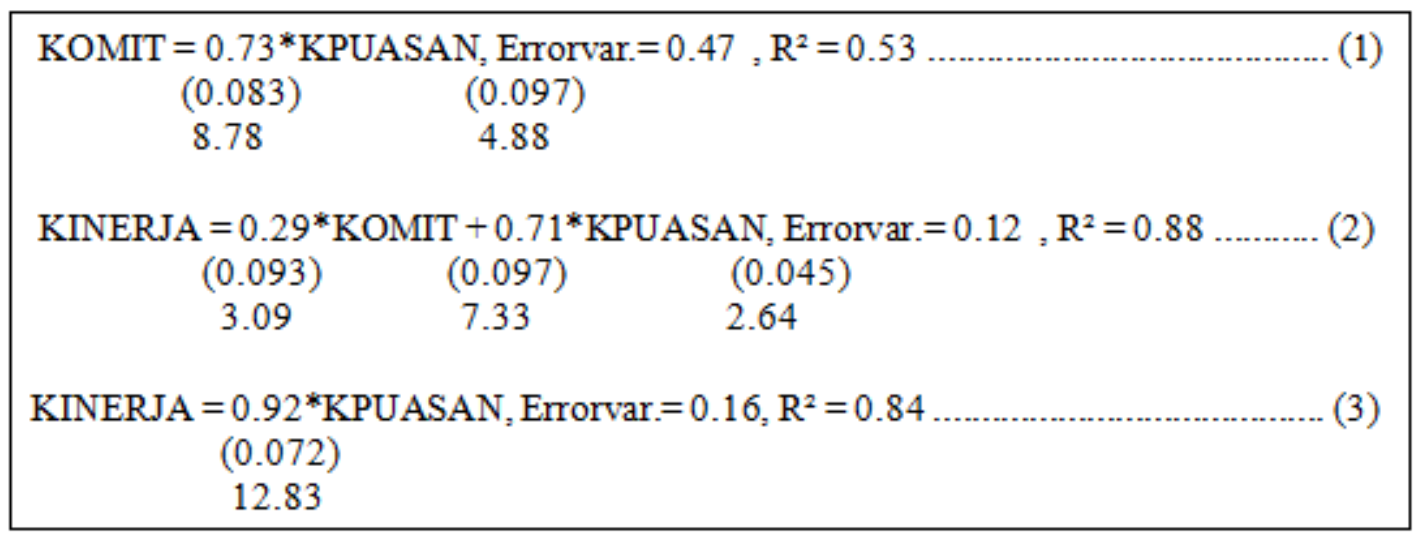

Berdasarkan Gambar 2, Gambar 3, dan Tabel 2 model persamaan struktural di atas, maka maka dapat dikemukakan hal-hal sebagai berikut: 
1) Besarnya koefisien jalur variabel kepuasan kerja terhadap komitmen organisasi adalah sebesar 0,73 dengan nilai $t_{\text {value }}$ sebesar 8,78>1,96, sehingga dapat dikatakan signifikan. Besarnya koefisien jalur tersebut menunjukkan bahwa besarnya kontribusi pengaruh kepuasan kerja terhadap komitmen organisasi sebesar 53\%. Sementara Besarnya koefisien jalur variabel kepuasan kerja terhadap kinerja karyawan adalah sebesar 0,71 dengan nilai $t_{\text {value }}$ sebesar 7,33>1,96, sehingga dapat dikatakan signifikan. Besarnya koefisien jalur tersebut menunjukkan bahwa besarnya kontribusi pengaruh kepuasan kerja terhadap kinerja karyawan sebesar 50\%. Dengan demikian maka kepuasan kerja terbukti berpengaruh positif dan signifikan terhadap komitmen organisasi dan kinerja karyawan atau Hipotesis kesatu diterima.

2) Besarnya koefisien jalur variabel komitmen organisasi terhadap kinerja karyawan adalah sebesar 0,29 dengan nilai $t_{\text {value }}$ sebesar 3,09 > 1,96, sehingga dapat dikatakan signifikan. Besarnya koefisien jalur tersebut menunjukkan bahwa besarnya kontribusi pengaruh komitmen organisasi terhadap kinerja karyawan sebesar $8,41 \%$. Dengan demikian maka komitmen organisasi terbukti berpengaruh positif dan signifikan terhadap kinerja karyawan atau Hipotesis kedua diterima.

3) Besarnya koefisien jalur variabel kepuasan kerja terhadap kinerja karyawan melalui komitmen organisasi adalah sebesar 0,21 dengan nilai $t_{\text {value }}$ sebesar 2,92 >1,96 (Sobel test), sehingga dapat dikatakan signifikan. Besarnya koefisien jalur tersebut menunjukkan bahwa besarnya kontribusi pengaruh kepuasan kerja terhadap kinerja karyawan melalui komitmen organisasi sebesar 4,48\%. Dengan demikian maka kepuasan kerja terbukti berpengaruh positif dan signifikan terhadap kinerja karyawan mealui komitmen organisasi atau Hipotesis ketiga diterima.

4) Besarnya koefisien determinasi $\left(R^{2}\right)$ variabel kepuasan kerja dan komitmen organisasi secara simultan terhadap kinerja karyawan adalah sebesar 0,88 dengan nilai $F_{\text {value }}$ sebesar $722.33>$ 3,84 , sehingga dapat dikatakan signifikan. Besarnya koefisien determinasi $\left(R^{2}\right)$ tersebut menunjukkan bahwa besarnya kontribusi pengaruh kepuasan kerja dan komitmen organisasi secara simultan terhadap kinerja karyawan sebesar $88 \%$, sementara sebesar $12 \%$ merupakan besar pengaruh diluar variabel yang diteliti. Adapun variabel yang paling dominan berpengaruh terhadap kinerja karyawan adalah variabel kepuasan kerja. Dengan demikian maka kepuasan kerja dan komitmen organisasi secara simultan terbukti berpengaruh positif dan signifikan terhadap kinerja karyawan atau Hipotesis keempat diterima.

Hasil pengujian di atas menunjukkan bahwa secara langsung variabel kepuasan kerja berpengaruh terhadap variabel kinerja karyawan dengan kontribusi sebesar 50\%. Variabel kepuasan kerja berpengaruh secara tidak langsung terhadap variabel kinerjan karyawan melalui 
komitmen organisasi dengan kontribusi sebesar 4,48\%. Sehingga kepuasan kerja secara langsung maupun tidak langsung melalui komitmen organisasi berpengaruh terhadap kinerja karyawan dengan kontribusi sebesar $84 \%$. Namun secara simultan kepuasan kerja dan komitmen organisasi berpengaruh terhadap kinerja karyawan dengan kontribusi sebesar $88 \%$. Hal ini menunjukkan bahwa komitmen organisasi dalam penelitian ini merupakan variabel partial mediating pada pengaruh variabel kepuasan kerja terhadap kinerja karyawan.

Sehingga temuan dari penelitian ini adalah untuk meningkatkan kinerja karyawan PT Perkebunan Nusantara VIII (Persero) Provinsi Jawa Barat terutama yang direfleksikan dengan tingginya dimensi kualitas kerja akan mampu ditingkatkan apabila perusahaan mampu meningkatkan komitmen organisasi terutama yang direfleksikan dengan tingginya dimensi komitmen kontinu, komitmen organisasi akan meningkat apabila perusahaan mampu meningkatkan kepuasan kerja karyawan terutama yang direfleksikan pada tingginya dimensi kepuasan atas hubungan rekan kerja.

\section{Kesimpulan}

1. Kepuasan kerja berpengaruh positif dan signifikan terhadap komitmen organisasi dan kinerja karyawan, hal ini menunjukkan bahwa peningkatan kepuasan kerja akan mengakibatkan meningkatnya komitmen organisasi dan kinerja karyawan pada PT Perkebunan Nusantara VIII (Persero) Provinsi Jawa Barat. Adapun yang paling dominan dalam mengukur kepuasan kerja karyawan direfleksikan dengan kepuasan atas hubungan dengan rekan kerja. Sementara Dimensi yang paling dominan dalam mengukur komitmen organisasi direfleksikan oleh dimensi komitmen kontinu terutama dalam hal tingkat kebutuhan atas pekerjaan dan kinerja karyawan direfleksikan oleh dimensi kualitas kerja terutama dalam tingkat kesesuaian hasil pekerjaan dengan standar pekerjaan.

2. Komitmen organisasi berpengaruh positif dan signifikan terhadap kinerja karyawan, hal ini menunjukkan bahwa peningkatan komitmen organisasi akan mengakibatkan meningkatnya kinerja karyawan PT Perkebunan Nusantara VIII (Persero) Provinsi Jawa Barat. Adapun yang paling dominan komitmen organisasi direfleksikan oleh dimensi komitmen kontinu terutama dalam hal tingkat kebutuhan atas pekerjaan, sementara kinerja karyawan direfleksikan oleh dimensi kualitas kerja terutama dalam tingkat kesesuaian hasil pekerjaan dengan standar pekerjaan.

3. Kepuasan kerja berpengaruh positif dan signifikan terhadap kinerja karyawan melalui komitmen organisasi, hal ini menunjukkan bahwa peningkatan kepuasan kerja akan mengakibatkan meningkatnya komitmen organisasi yang berimplikasi pada peningkatan kinerja karyawan PT Perkebunan Nusantara VIII (Persero) Provinsi Jawa Barat. 
4. Kepuasan kerja dan komitmen organisasi secara simultan berpengaruh positif dan signifikan terhadap kinerja karyawan, hal ini menunjukkan bahwa peningkatan kepuasan kerja dan komitmen organisasi secara simultan akan mengakibatkan meningkatnya kinerja karyawan PT Perkebunan Nusantara VIII (Persero) Provinsi Jawa Barat dengan kontribusi $\left(R^{2}\right)$ sebesar $88 \%$, secara parsial kepuasan kerja yang paling dominan dalam meningkatkan kinerja karyawan, sementara komitmen organisasi merupakan variabel partial mediating pada pengaruh kepuasan terhadap kinerja karyawan.

\section{Implikasi Manajerial}

Komitmen organisasi pada karyawan pada PT Perkebunan Nusantara VIII (Persero) Provinsi Jawa Barat terutama pada dimensi komitmen kontinu dengan indikator tingkat kebutuhan karyawan atas pekerjaan akan mampu ditingkatkan apabila PT Perkebunan Nusantara VIII (Persero) mampu meningkatkan kepuasan kerja karyawan terutama pada dimensi kepuasan atas rekan kerja dengan indikator tingkat hubungan dengan rekan kerja.

Kinerja karyawan PT Perkebunan Nusantara VIII (Persero) Provinsi Jawa Barat terutama pada dimensi kualitas kerja dengan indikator tingkat kesesuaian hasil pekerjaan dengan standar pekerjaan akan mampu ditingkatkan apabila PT Perkebunan Nusantara VIII (Persero) mampu meningkatkan komitmen organisasi terutama pada dimensi komitmen kontinu dengan indikator tingkat kebutuhan karyawan atas pekerjaan, dimana komitmen organisasi akan meningkat apabila PT Perkebunan Nusantara VIII (Persero) mampu meningkatkan kepuasan kerja karyawan terutama pada dimensi kepuasan atas rekan kerja dengan indikator tingkat hubungan dengan sesama rekan kerja karyawan. Demikian juga kinerja karyawan PT Perkebunan Nusantara VIII (Persero) akan mampu ditingkatkan secara langsung terutama pada dimensi kualitas kerja dengan indikator tingkat kesesuaian hasil pekerjaan dengan standar pekerjaan dengan meningkatkan kepuasan kerja karyawan terutama pada unsur kepuasan atas rekan kerja.

\section{Saran Manajerial}

1. Komitmen organisasi pada karyawan Unit Usaha PT Perkebunan Nusantara VIII (Persero) Jawa Barat sudah relatif tinggi sehingga akan mampu memberikan peningkatan pada kinerja karyawan dalam melaksanakan pekerjaannya. Peningkatan komitmen organisasi di pengaruhi oleh peningkatan kepuasan kerja karyawan terutama pada dimensi kepuasan atas rekan kerja. Beberapa indikator kepuasan kerja karyawan yang disarankan untuk tetap dipertahankan terutama pada indikator tingkat perhatian pimpinan, pekerjaan yang menarik, kesempatan untuk belajar, menerima tanggungjawab pekerjaan, kesempatan kenaikan jabatan, dan kesempatan mendapatkan pelatihan. Namun demikian masih terdapat beberapa indikator kepuasan kerja karyawan yang disarankan untuk diperhatikan dan ditingkatkan seperti pada indikator tingkat kepedulian pimpinan, penghargaan pimpinan, hubungan dengan rekan kerja, 
dukungan rekan kerja, bantuan dari rekan kerja, kesempatan melanjutkan pendidikan, pendapatan yang sesuai tanggungjawab pekerjaan, dan indikator pendapatan yang memenuhi kebutuhan dan tingkat insentif.

2. Kinerja karyawan Unit Usaha PT Perkebunan Nusantara VIII (Persero) Jawa Barat sudah relatif tinggi dalam melaksanakan pekerjaannya. Peningkatan kinerja karyawan dipengaruhi secara langsung maupun dimediasi oleh komitmen organisasi terutama pada dimensi komitmen kontinu. Beberapa indikator komitmen organisasi yang disarankan untuk tetap dipertahankan terutama pada indikator tingkat keterikatan emosional karyawan, kebutuhan atas pekerjaan, lamanya bekerja, dan tingkat kewajiban atas pekerjaan. Namun demikian masih terdapat beberapa indikator pada komitmen organisasi yang disarankan untuk diperhatikan dan ditingkatkan oleh Unit Usaha PT Perkebunan Nusantara VIII (Persero) seperti pada indikator tingkat identifikasi karyawan, keterlibatan karyawan, menerima aturan organisasi, serta tingkat moralitas untuk tinggal pada organisasi. Dimensi dominan dalam meningkatkan kinerja karyawan yaitu pada dimensi kualitas kerja. Beberapa indikator kinerja karyawan yang di sarankan untuk tetap dipertahankan terutama pada indikator tingkat ketepatan penyelesaian pekerjaan sesuai dengan waktu yang ditetapkan, kesesuaian hasil pekerjaan dengan standar pekerjaan, ketelitian dalam bekerja, kesesuaian hasil kerja dengan keterampilan dan pengetahuan, kerjasama dengan pimpinan, kreatifitas karyawan dalam menjaga lingkungan kerja, kepribadian karyawan dalam berkomukasi, dan indikator tingkat kemampuan dalam membantu karyawan lain.

\section{Saran untuk Peneliti Lebih Lanjut}

1. Masih banyak faktor lain yang mempengaruhi kinerja karyawan PT Perkebunan Nusantara VIII (Persero) Provinsi Jawa Barat, seperti kompetensi, motivasi, keterikatan kerja, pemberdayaan, kepemimpinan, kemampuan manajerial dan faktor lainnya agar diteliti lebih lanjut, karena mungkin saja ada faktor-faktor lain selain yang ada pada penelitian ini memiliki pengaruh dominan dalam meningkatkan kinerja karyawan.

2. Penelitian ini menggunakan variabel komitmen organisasi sebagai variabel mediasi, sehingga untuk penelitian selanjutnya kemungkinan akan menghasilkan temuan yang berbeda, apabila variabel komitmen organisasi yang digunakan sebagai variabel moderasi.

3. Penelitian ini menggunkan variabel komitmen organisasi sebagai variabel mediasi, sehingga untuk penelitian selanjutnya kemungkinan akan menghasilkan temuan yang berbeda, apabila variabel mediasi yang digunakan adalah variabel lain seperti organizational citizenship behavior.

4. Peneliian penelitian ini dapat juga dilakukan pada perusahaan perkebunan nusantara lainnya di Indonesia 
5. Penelitian ini dapat juga dilakukan pada perusahaan-perusahaan lainnya baik milik negara atau swasta baik tingkat provinsi maupun nasional.

\section{Daftar Pustaka}

Abdulrahman Ahmed Bako. 2012. The Positive and Negative Effects of Job Satisfaction on Employee's Performance in an Organization. Australian Journal of Commerce StudySCIE Journals

Achmad Bachrudin dan Harapan L. Tobing. 2003, Analisis Data untuk Peneloitian Survey dengan Menggunakan Lisrel 8 Dilengkapi Contoh Kasus, Jurusan Statistika, Bandung. FMIPA-Unpad.

Aftab Hira and Idrees Waqas. 2012. A Study of Job Satisfaction and IT's Impact on the Performance in the BankingIndustry of Pakistan. International Journal of Business and Social Science Vol. 3 No. 19

Arikunto, Sukarsimi. 2002. Prosedur Penelitian Suatu Pendekatan Praktek. Jakarta : PT. Rineka Cipta.

Awadh, Alharbi M and Saad, Alyahya M. 2013. "Impact of Organizational Culture on Employee Performance". International Review of Management and Business Research. Vol. 2 Issue.1

BPS. 2017.Proyeksi Penduduk Indonesia. ISBN: 978-979-064-606-3

Fao Statistical Yearbook. 2016. World Food and Agriculture. ISBN 978-92-5-107396-4, Gate Harlow: Prentice Hall, Inc.

George, J. M., G. R. Jones. 2012. Understanding and Managing Organizational Behavior. New Jersey: Prentice Hall.

Gibson, James L., John M. Ivancevich, James H. Donnelly, Jr., and Robert Konopaske. 2012. Organizations; Behavior, Structure, Processes (Singapore: McGraw-Hill).

Gomes, Faustino Cardoso. 2005. Manajemen Sumber Daya Manusia. Yogyakarta: CV. Andi Offset.

Hair et al., 2006, Multivariate Data Analysis, Fifth Edition, Prentice Hall, Upper Saddle River : New Jersy.

Hellriegel, Donand John W. Slocum Jr. 2011. Organizational Behavior, Australia: SouthWestern, Cengage Learning.

Kiran Fatima and Samreen Lodhi. 2015. Impact of Employees Performance on Achievement of Organization Goals: A Case of Karachi, Pakistan. The International Journal Of Business \& Management (ISSN 2321-8916), Vol 3 Issue 11

Luthans, F. 2011. Organizational Behavior, 12th ed, Mc.Graw-Hill International Editions

Mahmood, Iqbal dan Samsaa. 2014. The Relationship between Role Ambiguity, Competency and Person-Job Fit With the Job Performance of Employees in the Service Sector SMEs in Malaysia. Business Management Dynamics, Vol.1, No.2.

Mangkunegara, Anwar Prabu. 2007. Evaluasi Kinerja SDM. Bandung : PT.Refika Aditama

Memari, Negin., Mahdieh Omi dan Barati, Ahmad Marnani. 2013. The impact of Organizational Commitment on Employees Job Performance. Interdiciplinary Journal of Contemporary Research in Business, Vol. 5, No. 5

Muhammad Riaz Khan, Ziauddin, Farooq Ahmed Jam, M. I. Ramay. 2010. The Impacts of Organizational Commitment on Employee Job Performance. European Journal of Social Sciences - Volume 15, Number 3.

PTPN VIII. 2016. Laporan Tahunan PT Perkebunan Nusantara VIII (Persero) 2016.

Robbins, Stephen P. and Timothy A. Judge.2013. Organizational behavior. Singapore: Person international.

Rismayadi, Budi. 2017. The Influence of Organizational Culture, Soft Skill, and Leadership on Organizational Commitment and its implication at educator Performance (Empirical 
Reaserch on Community Learning Center Karawang District, Wet Java Indonesia). International Journal of Applied Business and Economic Research, Vol. 15 No. 20.

Sekaran, U. dan Bougie, R. 2011. Research methods for business: a skill building approach. Wiley, United Kingdom

Sugiyono. 2010. Metode Penelitian Kuantitatif Kualitatif dan R\& D, Alfabeta Bandung.

The Tea Board Of India. 2010. Annual Report \& Accounts 2009/2010.

The Tea Board Of Kenya. 2009. Annual Report \& Accounts 2008/2009.

Ulker Colakoglu, Osman Culha, and Hakan Atay. 2010. The Effects Of Perceived Organisational Support On Employees' Affective Outcomes: Evidence From The Hotel Industry. Tourism and Hospitality Management, Vol. 16, No. 2, pp. 125-150.

Zikmund, William G., Barry J. Babin, Jon C. Carr, and Mitch Griffin. 2008, Business Research Methods, Eighth Edition, Philadelphia, The Dryden Press. 